\title{
Relationships between Lecturer Performance, Organizational Culture, Leadership, and Achievement Motivation
}

\author{
Yusdi Anra a \\ Lecturer, Faculty of Education and Teacher Training, yusdiandra@yahoo.com \\ Martinis Yamin a;b \\ Lecturer, Faculty of Education and Teacher Training; and Expert, martinisyamin@yahoo.co.id \\ a Jambi University, Jl. Lintas Jambi - Muara Bulian Km. 15, Mendalo Darat, Jambi Luar Kota, Kota Jambi, \\ Jambi 36122, Indonesia. \\ ${ }^{\mathrm{b}}$ State Institute for Islamic Studies, Sulthan Thaha Saifuddin Jambi, Indonesia.
}

\begin{abstract}
$\mathrm{T}$
This research is aimed at finding the effects of: 1) organizational culture on performance, 2) leadership on performance; 3) achievement motivation on performance; 4) organizational culture on achievement motivation; 5) leadership on achievement motivation. This research used a survey method with a causal approach. There were 255 lecturers selected from initial population of 706 individuals based on a simple random technique as the sample. This research was conducted using questionnaires given to lecturers in Jambi University. The validity test was conducted using the Cronbach's alpha.
\end{abstract}

Abstract

\section{Keywords:}

performance;

organizational culture;

leadership;

achievement motivation.
The results showed that: first, there was a direct effect of organizational culture on performance; second, there was a direct effect of leadership on performance; third, there was a direct effect of achievement motivation on performance; fourth, there was a direct effect of organizational culture on achievement motivation; fifth, there was a direct effect of leadership on achievement motivation. The implication of this research is that the effort to improve lecturer performance can be made by improving the organizational culture, leadership, and achievement motivation.

Citation: Anra Y., Yamin M. (2017) Relationships between Lecturer Performance, Organizational Culture, Leadership, and Achievement Motivation. Foresight and STI Governance, vol. 11, no 2, pp. 92-97.

DOI: $10.17323 / 2500-2597.2017 .2 .92 .97$ 
$\mathrm{L}$ ecturer performance is a key aspect of the quality of a university's educational program. Good performance by a single lecturer can have a positive impact on the university as a whole, therefore the university can arrange an optimal work program in order to improve the quality of the university. There are many factors influencing lecturer performance, one of which is the number of students. The higher the number of students, the higher the teaching load on a lecturer, which in turn can affect his/her performance at the university.

Jambi University was established on April 1, 1969 and initially consisted of the Faculty of Economics, Faculty of Law, the Faculty of Agriculture, and the Faculty of Animal Husbandry ${ }^{1}$. Later, in 1982, there a Decree of the President of the Republic of Indonesia was issued that stipulated that Jambi University would consist of the Faculty of Teacher Training and Education, the Faculty of Economics, the Faculty of Law, the Faculty of Agriculture, and the Faculty of Animal Husbandry ${ }^{2}$. According to University's Bureau for Administration and Finance as of 2012, Jambi University employed 717 lecturers at the 5 faculties, as follows: 205 lecturers in the Faculty of Teacher Training and Education (FKIP), 129 in the Faculty of Economics (FE), 103 in the Faculty of Law (FH), 170 in the Faculty of Agriculture (FAPERTA), and 110 in the Facutly of Animal Husbandry (FAPET) [Jambi University, 2012]. However, the number of lecturers is still lower than the number of the students at Jambi University, there are currently 28,000 students, with a teacher to student ratio of 1:39. The ideal ratio of the number of lecturers and the number of students is 1:20.

Daft [Daft, 2003, p. 22] defines performance as, in a broader definition, an organization's ability to achieve its goals, accomplish its tasks and implement its strategies. An organization should have clarity, both in its objectives and strategies. There are four ways to achieve effective performance at an organization [Robbins, 1990, p. 77]: 1) goal attainment, how an organization is able to attain its final goals that have been set down its development program, 2) the system, how an organization is able to obtain the necessary resources, 3) strategic constituencies, how an organization can bring its targets into line with the objectives of strategic constituencies, 4) competing values, an effective organization's ability to compete within the broader environment.

The individual outcomes at an organization, which are understood as performance and organizational commitment are affected by several factors [Colquitt et al., 2009, p. 8]: 1) job satisfaction; 2) stress levels; 3) motivation; 4) trust, justice, and ethics; and 5) learning and decision making. Performance is a valuable asset and entails the set of behavioral characteristics of possessed by an employee, which has both positive and negative consequences for the achievement of an organization's goals [Ibid., p. 37].

A lecturer is obliged to guide his/her students in the interests of state education, in other words, a lecturer must have certain professional skills [Hamalik, 1989, p. 123]. As a professional, a lecturer at Jambi University has the following duties: 1) to help implement both the academic and non-academic programs of the university, (2) to use all available means to provide high-quality teaching and education, (3) have to preserve and develop knowledge by implementing the three pillars of tertiary education (tridharma perguruan tinggi): education and teaching, research, and community service [Jambi University, 2009, p. 11].

Jambi University is among those organizations at which lecturer performance plays an important role in improving the quality of its graduates. The improvement in lecturer performance demands more time and effort from the faculty and university as a whole in order to accelerate the achievement of the university's visions and mission. Based on the definition above, it can be stated that lecturer performance at Jambi University involves the lecturers' ability to conduct their duties and functions in line with the university's organizational goals, which are expressed in qualitative and quantitative indicators including professional skills, working knowledge, creativity, cooperation within a team, subordination, initiative, and individual characteristics.

Furthermore, the organizational culture consists of a set of values that are shared by all employees, which provide the members of the organization with guarantees and help. The reproduction of this culture is attained through the dissemination of social knowledge among the organization, which is based on the rules, norms, values, attitude and behavior of the employees. "A shared social knowledge within an organization regarding the rules, norms, and values shapes the attitude and behaviors of its employees" [Colquitt et al., 2009, p. 546].

Diana C. Pheysey [Pheysey, 1993, p. 3] defines culture as a way of encouraging habits among a large number of people. Culture opens one to changes. Therefore, Diana Pheysey defines culture as follows: "A culture is thus a way of seeing what is common to many people. Culture itself is subject to [constant] transformation". In other words, Diana C. Pheysey wanted to say that culture is usually used as a source of guidance by all of its proponents and it also serves as a source of change. Thus, the organizational culture at Jambi University is not constant or eternal, but can change at anytime, if such a change is supported by its members.

The organizational culture at Jambi University contains both formal and informal components, values that govern the behavior of both individuals and groups. Interactions between individuals and groups

${ }^{1}$ Decree of the Minister of Education No. 25 of 1963.

${ }^{2}$ Decree of President of the Republic of Indonesia No. 41 of 1982. 
at the organization are controlled by the values and norms of the university. It is necessary to have control mechanisms in place, which have been mutually agreed upon and accepted in order to ensure that individual behavior does not deviate from the aforementioned values and norms. Based on the description above, organizational culture can be defined as a set of values that is accepted by the members of an organization as a guiding principle for action. Manifestations of this organizational culture include tolerance, respect for authority, integrity, loyalty, cooperation, mutual respect, confidence, attention, sacrifice, transparency, and dedication to one's work.

Leadership is understood as a dynamic process tied to one's ability to influence others. The source of this influence may be formally proscribed or informal, carried out on the basis of one's relationships. Strong leadership and management are needed to improve lecturer performance at Jambi University. Hersey and Blanchard [Hersey, Blanchard, 1985, p. 86] define leadership as a process in which authority is exercised in order to achieve a goal in a certain situation. A leader needs authority, but this does not mean more power is always better. Leadership is comprised of five types of authority [French, Raven, 1959; Yukl, 2011, p. 190]: (1) Incentive power, a reward is given on the basis of a person's ability as determined by the leader; (2) Coercive power, the imposition of a leader's will on a person, who follows the commands to avoid punishment; (3) Legitimate power, authority, which is set down in law or regulations and entitles the one with it to issue binding orders; (4) Expert power, the authority to use one's expert knowledge to complete a job; (5) Charismatic power, the power of a person who is admired by the others due to his/her nature and appeal.

Emmy and Taty [Emmy, Taty, 1994, p. 110] state that leadership is task-oriented and focused on observing the interests of one's employees. There are four leadership strategies [Robbins et al., 2013]: (1) the leader who directs his or her followers, lets them know what should be expected from him or her, determines the schedule and gives specific guidelines for the completion of tasks, (2) a charming, friendly leader who cares about the needs of his followers, (3) an involved leader, who is open to communication with his or her subordinates and discusses goals before making a decision, (4) a leader, focused on achievements, who sets challenging goals and expects his or her subordinates to perform at their highest level.

Gibson, Donelly and Ivancevich [Gibson et al., 1996, p. 3] define leadership as the ability to influence others and imbue them with a sense enthusiasm in striving to achieve the set goals. This definition stipulates a change of the subject itself, which influences others. A similar opinion is also expressed by Matondang [Matondang, 2008, p. 5] who defines leadership as a process of influencing other people to do or not do a certain task. The definition by Matondang stipulates a university leader's attitudes and patterns of behavior as well as the use of one's authority to influence other people in the achievement of certain goals.

Based on the definitions above, it can be stated that leadership at Jambi University includes the behavior and actions, which are reflected in the changes of the person who influences others, both individuals and groups, to achieve organizational goals. On the surface this process is expressed in quick decision making, the organization of work, the provision of guidance, encouragement, responsibility and attention, the correction of mistakes, the encouragement of cooperation and the development of policy.

Similarly, the motivation a lecturer to achieve his/her goals lies in his/her ability to motivate him-/herself in overcoming the challenges and obstacles that lie in the way of achieving said goals. Danim and Suparno [Danim, Suparno, 2008, p. 33] focus on three needs, they are: the needs for achievement, affiliation, and power. The first encompasses Jambi Univerity employees' internal motivation to perform their duties by improving their teaching performance in order to bring the organization closer to achieving its goals. Such motivation is considered a condition that allows lecturers to bring their behavior into line with organizational tasks. Furthermore, another approach was expressed by Siagian [Siagian, 1989, p. 128] in which professional motivation includes a whole number of factors, which turn workers into dedicated employees who are willing to work sincerely for the sake of achieving an organization's goals in the most efficient and economical manner possible.

Therefore, lecturers' motivation to achieve at Jambi University includes the individual's motivation to think, act, work, and overcome any obstacle when fulfilling one's duties. Indicators of this motivation include hopes for success, fear of failure, one's competitive spirit and diligence.

This study was conducted to order to determine whether the organizational culture, leadership and motivation to achieve have a direct effect on lecturer performance at Jambi University.

\section{Research Methodology}

This research used the survey method by distributing questionnaires to the target respondents. This target population is comprised of lecturers at Jambi University. The sample included 706 lecturers at Jambi University, who had been civil servants for at least three years. Data was gathered using the path analysis method, while the sample was collected by using probability sampling. The sample was collected by providing every individual in the population an equal chance of being included in the sample. The data were collected using questionnaires as the research instrument, these questionnaires were developed based on a conceptual and operational definition, and a matrix analysis of each research variable. 
Table 1. Path coefficients of the first structural model (dependent variable - lecturer performance)

\begin{tabular}{|l|l|l|l|c|c|}
\hline \multirow{2}{*}{ Model } & \multicolumn{2}{c|}{$\begin{array}{c}\text { Unstandardized } \\
\text { coefficients }\end{array}$} & $\begin{array}{c}\text { Standardized } \\
\text { coefficients }\end{array}$ & \multirow{2}{*}{$\begin{array}{c}\text { t-test } \\
\text { Beta-coefficient }\end{array}$} & $\begin{array}{c}\text { Significance } \\
\text { level (Sig) }\end{array}$ \\
\cline { 2 - 6 } & \multicolumn{1}{|c|}{ B-coefficient } & Standard error & & 0.377 & 0.706 \\
\hline (Constant) & 2.800 & 7.418 & & 2.855 & 0.005 \\
\hline Organizational culture $\mathrm{X}_{1}$ & 0.223 & 0.078 & 0.222 & 4.701 & 0.000 \\
\hline Leadership $\mathrm{X}_{2}$ & 0.379 & 0.081 & 0.368 & 5.039 & 0.000 \\
\hline Achievement motivation $\mathrm{X}_{3}$ & 0.260 & 0.052 & 0.255 & & \\
\hline \multicolumn{2}{|l|}{ Source: calculated by the authors. }
\end{tabular}

The subject of analysis is the impact of organizational culture, leadership and individual motivation to achieve on the teaching performance of lecturers at Jambi University. A validation test showed that the significance of each research variable allows for further statistical tests. The research hypothesis was tested by calculating the path coefficients based on the proposed hypothesis, they were $\mathrm{P}_{\mathrm{y} 1}, \mathrm{P}_{\mathrm{y} 2}, \mathrm{P}_{\mathrm{y} 3}, \mathrm{P}_{\mathrm{y} 4}, \mathrm{P}_{31}$ and $\mathrm{P}_{32}$. Path coefficient calculations were conducted using SPSS software.

\section{Results}

The results of the Lilliefors Test, a normality test, allowed us to form the following statistical hypotheses:

$H_{0}$ : the population data has an estimation error with normal distribution

$H_{1}$ : the population data has an estimation error with unusual distribution.

The provision in this test is that if the statistic of $\mathrm{L}_{\text {count }}\left(\mathrm{L}_{0}\right)<\mathrm{L}_{\text {table }}(\alpha=0.05)$, then the data error will have a normal distribution. Otherwise, if $\mathrm{L}_{\text {count }}\left(\mathrm{L}_{0}\right)>\mathrm{L}_{\text {table }}(\alpha=0.05)$, then the data will have a non-normal distribution. (1) Initially, a normality test of the error score of lecturer performance on organizational culture $\left(\mathrm{X}_{4}\right.$ on $\left.\mathrm{X}_{1}\right)$ was conducted. The Liliefors statistical calculation obtained the following result: $\mathrm{L}_{\text {count }}=0.0527$. It is lower than $\mathrm{L}_{\text {table }}(\mathrm{n}=225 ; \alpha=0.05)=0.0555$. Thus, it can be said that the distribution of the estimation error of lecturer performance $\left(\mathrm{X}_{4}\right)$ on organizational culture $\left(\mathrm{X}_{1}\right)$ has resulted from a normally distributed population. (2) Next, a normality test of the error score of lecturer performance on leadership $\left(\mathrm{X}_{4}\right.$ on $\left.\mathrm{X}_{2}\right)$ was conducted. The Liliefors statistical calculation obtained $\mathrm{L}_{\text {count }}=0.0534$. It is lower than $\mathrm{L}_{\text {table }}(\mathrm{n}=225 ; \alpha=0.05)=0.0555$. Thus, it can be said that the distribution of estimation error of lecturer performance $\left(\mathrm{X}_{4}\right)$ on leadership $\left(\mathrm{X}_{2}\right)$ has resulted from a normally distributed population. (3) Then a normality test of the error score of lecturer performance on achievement motivation $\left(\mathrm{X}_{4}\right.$ on $\mathrm{X}_{3}$ ) was carried out. The Liliefors statistical calculation obtained $\mathrm{L}_{\text {count }}=0.0522$. It is lower than $\mathrm{L}_{\text {table }}$ $(n=225 ; \alpha=0.05)=0.0555$. Therefore, it can be said that the distribution of the estimation error of lecturer performance $\left(\mathrm{X}_{4}\right)$ on achievement motivation $\left(\mathrm{X}_{3}\right)$ is the result of a normally distributed population. Furthermore, the results of the calculation of Substructure 1 of the effects of $x_{1} x_{2}$ and $x_{3}$ on $\mathrm{x}_{4}$ can be seen in the Table 1 :

Based on the information presented in Table 1 above, the standardized value of the regression coefficient (Beta) for Organizational Culture $\left(\mathrm{X}_{1}\right)$ on Lecturer Performance $\left(\mathrm{X}_{4}\right) \mathrm{P}_{\mathrm{y} 1}$ is 0.222 ; for Leadership $\left(\mathrm{X}_{2}\right)$ on Lecturer Performance $\left(\mathrm{X}_{4}\right) \mathrm{P}_{\mathrm{y} 2}$ is 0.368 ; and for Achievement Motivation $\left(\mathrm{X}_{3}\right)$ on Lecturer Performance $\left(\mathrm{X}_{4}\right) \mathrm{P}_{\mathrm{y} 3}$ is 0.255 . Thus, the formed path coefficients in the first equation model are as follows:

$\mathrm{P}_{\mathrm{yl}}=0.222$

$\mathrm{P}_{\mathrm{y} 2}^{\mathrm{y} 1}=0,368$

$\mathrm{P}_{\mathrm{y} 3}^{\mathrm{y} 2}=0.255$

The results of the calculation of Substructure 1 of the effects of $x_{1} x_{2}$ and $x_{3}$ can be seen in Table 2 below. Based on the results presented in Table 2, the standardized value of regression coefficient (Beta) for Organizational Culture $\left(\mathrm{X}_{1}\right)$ on Achievement Motivation $\left(\mathrm{X}_{3}\right) \mathrm{P}_{31}$ is 0.255 ; and for Leadership $\left(\mathrm{X}_{2}\right)$ on Achievement Motivation $\left(\mathrm{X}_{3}\right) \mathrm{P}_{32}$ is 0.303 . Thus, the formed path coefficients in the second equation model are as follows:

\begin{tabular}{|c|c|c|c|c|c|}
\hline \multirow{2}{*}{ Model } & \multicolumn{2}{|c|}{$\begin{array}{c}\begin{array}{c}\text { Unstandardized } \\
\text { coefficients }\end{array} \\
\end{array}$} & \multirow{2}{*}{$\begin{array}{c}\begin{array}{c}\text { Standardized } \\
\text { coefficients }\end{array} \\
\text { Beta-coefficient } \\
\end{array}$} & \multirow{2}{*}{ t-test } & \multirow{2}{*}{$\begin{array}{c}\text { Significance } \\
\text { level (Sig) }\end{array}$} \\
\hline & B-coefficient & Standard error & & & \\
\hline (Constant) & 41.377 & 8.654 & & 4.781 & 0.000 \\
\hline Organizational culture $\mathrm{X}_{1}$ & 0.251 & 0.094 & 0.255 & 2.673 & 0.008 \\
\hline Leadership $\mathrm{X}_{2}$ & 0.306 & 0.096 & 0.303 & 3.178 & 0.002 \\
\hline
\end{tabular}


Table 3. Illustration of the calculation of path coefficients

\begin{tabular}{|c|c|c|c|c|c|}
\hline \multirow{2}{*}{ Path } & Path coefficient & \multirow{2}{*}{$\mathbf{t}_{\text {count }}$} & \multicolumn{2}{|c|}{$\mathbf{t}_{\text {table }}$} & \multirow{2}{*}{ Information } \\
\cline { 4 - 6 } & & & $\mathbf{( a = 0 . 0 5 )}$ & $\mathbf{( a = 0 . 0 1 )}$ & Very significant \\
\hline $\mathrm{X}_{1} \rightarrow \mathrm{X}_{4}$ & $\mathbf{p}_{\mathrm{y} 1}=0.222$ & 2.855 & 1.6510 & 2.3414 & Very significant \\
\hline $\mathrm{X}_{2} \rightarrow \mathrm{X}_{4}$ & $\mathbf{p}_{\mathrm{y} 2}=0.368$ & 4.701 & 1.6510 & 2.3414 & Very significant \\
\hline $\mathrm{X}_{3} \rightarrow \mathrm{X}_{4}$ & $\mathbf{p}_{\mathrm{y} 3}=0.255$ & 5.039 & 1.6510 & 2.3414 & Very significant \\
\hline $\mathrm{X}_{1} \rightarrow \mathrm{X}_{3}$ & $\mathbf{p}_{31=} 0.524$ & 2.673 & 1.6510 & 2.3414 & Very significant \\
\hline $\mathrm{X}_{2} \rightarrow \mathrm{X}_{3}$ & $\mathbf{p}_{32=} 0.303$ & 3.178 & 1.6510 & 2.3414 & \\
\hline
\end{tabular}

$\mathrm{P}_{31}=0.255$

$\mathrm{P}_{32}=0.303$

The results of the calculaltion of the path coefficients of the exogenous variables on the endogenous variables are illustrated in Table 3.

The calculation for the first hypothesis obtained $t_{\text {count }}=2.855$, which is higher than $t_{\text {table }(0.01)}=2,3414$. Since the $\mathrm{t}_{\text {count }}>\mathrm{t}_{\text {table }}$ or $2.855>2.3414$, then $\mathrm{H}_{0}$ is rejected. Thus, it can be concluded that organizational culture $\left(\mathrm{X}_{1}\right)$ directly affects lecturer performance $\left(\mathrm{X}_{4}\right)$. The calculation for the second hypothesis obtained $\mathrm{t}_{\text {count }}=$ 4.701, which is higher than $\mathrm{t}_{\text {table }(0.01)}=2.3414$. Since the $\mathrm{t}_{\text {count }}>\mathrm{t}_{\text {table }}$ or $4.701>2.3414$, then $\mathrm{H}_{0}$ is rejected. Thus, it can be concluded that leadership $\left(\mathrm{X}_{2}\right)$ directly impacts lecturer performance $\left(\mathrm{X}_{4}\right)$. The calculation for the third hypothesis obtained $t_{\text {count }}=5.039$, which is higher than $t_{\text {table }(0.01)}=2.3414$. Since the $t_{\text {count }}>$ $\mathrm{t}_{\text {table }}$ or $5.039>2.3414$, then $\mathrm{H}_{0}$ is rejected. Thus, it can be concluded that achievement motivation $\left(\mathrm{X}_{3}\right)$ has a direct impact on lecturer performance $\left(\mathrm{X}_{4}\right)$. The calculation for the fourth hypothesis obtained $\mathrm{t}_{\text {count }}=2.673$, which is higher than $\mathrm{t}_{\text {table (0.01) }}=2.3414$. Since the $\mathrm{t}_{\text {count }}>\mathrm{t}_{\text {table }}$ or $2.673>2.3414$, then $\mathrm{H}_{0}$ is rejected. Thus, it can be concluded that organizational culture $\left(\mathrm{X}_{1}\right)$ directly influences achievement motivation $\left(\mathrm{X}_{3}\right)$. The calculation for the fifth hypothesis obtained $t_{\text {count }}=3.178$, which is higher than $\mathrm{t}_{\text {table (0.01) }}=2.3414$. Since the $\mathrm{t}_{\text {count }}>\mathrm{t}_{\text {table }}$ or $3.178>2.3414$, then $\mathrm{H}_{0}$ is rejected. Thus, it can be concluded that leadership $\left(\mathrm{X}_{2}\right)$ has a direct effect on achievement motivation $\left(\mathrm{X}_{3}\right)$.

\section{Discussion}

The findings showed that organizational culture has a direct effect on lecturer performance at Jambi University. The findings of this research suggest that efforts made to improve the quality of tertiary education should begin in human resources (HR) departments. The mission of Jambi University, stipulates "the provision of an education by qualified personnel and a healthy academic climate, the conduct of research that supports national development and encourages the achievement of the strategic goals of Jambi University to be an advanced university in the national education system".

According to Indonesian legislation, specifically law number 14 of 2005 concerning teacher and lecturers ${ }^{3}$, the profession of lecturer and teacher is a special field guided by certain principles: 1) one should be distinguished by one's talent, interest, and idealism; 2) demonstrate a commitment to improving the quality of education, decency, conscientiousness, and noble character; 3 ) possess academic qualifications and an educational background suited to one's position; 4) be responsible for the implementation of professional duty; 5) obtain income based on one's achievements; 6) be given the opportunity to develop his/her qualifications through life-long learning; 7) possess legal guarantees for doing one's professional duty; 8) belong to a professional organization that is authorized to regulate issues related to the professional responsibilities of a lecturer.

The findings of this research are in line with the integrative model of the organizational approach of Colquitt, Lepine and Wesson [Colquitt et al., 2009, p. 8], in which performance within an organization is closely related to an employee's commitment to basic corporate targets, namely organizational culture, leadership, and the motivation to achieve. Leadership is very important in order to understand how people are able to exert their influence within an organization, while subjects have the ability to influence one another [Mitzberg, 1983; Pfeffer, 1992; Yukl, 2011, p. 172].

Lecturer performance at Jambi University depends on whether a leader is able to positively influence the lecturers and facilitate their optimal development. Meanwhile, the motivation to achieve finds similar significance, as it has a direct effect on lecturer performance at Jambi University. This motivation is particularly important for employees. Danim and Suparno [Danim, Suparno, 2008, p. 33], state that lecturers' social lives are mostly conducted on the campus where they work. A conducive environment will encourage their professional growth through competition with their colleagues. This healthy competition will be a factor in the future development of the individual.

\footnotetext{
${ }^{3}$ Republic of Indonesia Law on Teachers and Lecturers No. 14/2005.
} 
Our findings are also in line with the theory of the motivation to achieve [McClelland, 1988; Danim, Suparno, 2008, p. 34], which states that humans need to have achievements, affiliation, and power. These needs can be fulfilled only if the lecturers are given far-reaching opportunities for professional development by the management of Jambi University. The fulfillment of tasks delegated by management not only requires time from employees, but also the relevant infrastructure, an atmosphere of trust and confidence, and appropriate rewards and remunerations.

Organizational culture has a direct effect on the motivation to achieve. The results of the research conducted with Jambi University employees allowed us to empirically confirm the theory proposed by Stephen Robbins [Robbins et al., 2013], which postulates that organizational culture is characterized by ten traits: individual initiative, risk tolerance, governance, integration, administrative support, control, identity, reward, conflict tolerance, and communication patterns. In order to further develop these conclusions, one must study the degree to which the various traits described in Robbins's theory are present and cultivated at Jambi University.

The result of the test on the fifth hypothesis showed that the leadership variable has a direct effect on achievement motivation. Empirically, evidence from the research conducted at Jambi University is in line with the model of organizational behavior [Colquitt et al., 2009, p. 8], in which organizational culture, leadership, and the motivation to achieve become the background for achievement and performance within an organization. In this context, the organization is a university, that is, Jambi University, and how it conducts its daily learning activities within its academic programs. The leader therefore mobilizes the potential of lecturers so that they can reach their goals. Hersey and Blanchard [Hersey, Blanchard, 1985 , p. 86] argue that leadership is the process of managing one's authority to achieve set goals. Gibson, Donelly and Ivancevich [Gibson et al., 2006, p. 21] suggest that leadership is the ability to influence other people and imbue them with the enthusiasm necessary to accomplish those goals. A university leader, especially at Jambi University, should be in a position to meet the needs of his/her employees, in particular concerning career development, which is possible if lecturers have attained considerable achievements.

\section{Conclusions}

Our analysis has allowed us to draw the following conclusions. Organizational culture directly impacts one's motivation to achieve, which is the case for the lecturers at Jambi University. The type of leadership determines the character of this motivation, and effective management leads to increased motivation and enthusiasm. In turn, the motivation to achieve directly impacts lecturer performance: when motivation is higher, the lecturers perform better. Performance also is directly dependent on the organizational culture that is in place, and the example of Jambi University serves to confirm this assertion. Finally, the results of teaching activity are determined by the quality of leadership. If there is effective leadership, then lecturers' work will be similarly effective.

\section{References}

Colquitt J.A., LePine J.A., Wesson M.J. (2009) Organizational Behavior: Improving Performence and Committment in the Workplace, New York: McGraw Hill.

Daft R.L. (2003) Management (6th ed.), Mason, OH: South Western.

Emmy F.G., Taty R. (1994) Kepemimpinan Pendidikan dalam Pengelolaan Pendidikan [Educational Leadership in Management Education], Bandung (Indonesia): Universitas Pendidikan (in Indonesian).

French J., Raven B.H. (1959) The Bases of Social Power. Studies of Social Power (ed. D. Cartwright), Ann Arbor, MI: Institute for Social Research, pp. 150-167.

Gibson J.L., Donelly J.H. (Jr.), Ivancevich J.M. (2006) Manajemen [Management], Jakarta (Indonesia): Erlangga (in Indonesian).

Hamalik O. (1989) Manajemen Belajar di Perguruan Tinggi [Learning Higher Education Management], Bandung (Indonesia): Sinar Baru (in Indonesian).

Hersey P., Blanchard K.H. (1985) Management of Organizational Behavior, Singapoure: Prentice Hall.

Jambi University (2009) Buku Pedoman Unversitas Jambi [Guidelines of Jambi University], Jambi (Indonesia): Jambi University (in Indonesian).

Jambi University (2012) Biro Administrasi Umum dan Keuangan Melaporkan [Bureau for Administration and Finance Report], Jambi (Indonesia): Jambi University (in Indonesian).

Matondang M.H. (2008) Kepemimpinan Budaya Organisasi dan Manajemen Strategik [Organizational Culture Leadership and Strategic Management], Yogyakarta (Indonesia): Graha (in Indonesian).

McClelland D. (1988) Human Motivation, New York; New Rochelle; Melbourne; Sydney: Cambridge University Press.

Pfeffer J. (1992) Managing with power: Politics and influence in organizations, Boston, MA: Harvard Business School Press.

Pheysey D.C. (1993) Organization Cultures: Types and Transformation, New York: Routledge.

Robbins S. (1990) Organization Theory, Structure, Design, and Application, Englewood Cliffs, NJ: Prentice Hall, Inc.

Robbins S., Judge T.A., Millett B., Boyle M. (2013) Organisational Behaviour (7th ed.), Frenchs Forest, NSW: Pearson Higher Education Australia.

Siagian S.P. (1989) Teori Motivasi dan Aplikasinya [Motivation Theory and Its Application], Jakarta (Indonesia): Rineka Cipta (in Indonesian).

Sudarwan D., Suparno A. (2008) Manajemen dan Kepemimpinan Transformasional Kepala Sekolah [Management and Transformational Leadership], Jakarta: Rineka Cipta (in Indonesian).

Yukl G. (2011) Leadership in Organization (5th ed.), New York: Prentice-Hall, Inc. 